\title{
The Logic of the Transformation of ROK-U.S Alliance's Influence on the Geopolitical Pattern of Korean Peninsula
}

\author{
Meifang Xue ${ }^{1}$, Dunqiu $\mathrm{Li}^{2}$ \\ ${ }^{1}$ School of Politics and Public Administration, China University of Political Science and Law, Beijing, China \\ ${ }^{2}$ The Center for Countries and Regional Studies, Qufu Normal University, Qufu, China
}

Email address:

m18810332794@163.com (Meifang Xue),jin816816@163.com (Dunqiu Li)

\section{To cite this article:}

Meifang Xue, Dunqiu Li. The Logic of the Transformation of ROK-U.S Alliance's Influence on the Geopolitical Pattern of Korean Peninsula. Journal of Political Science and International Relations. Vol. 4, No. 2, 2021, pp. 24-32. doi: 10.11648/j.jpsir.20210402.11

Received: March 15, 2021; Accepted: April 6, 2021; Published: April 13, 2021

\begin{abstract}
This study mainly combines the historical evolution of the Korea-U.S. alliance (vertical) with international politics' current situation dynamics (horizontal). It explores the correlation between the transformation direction of the Korea-U.S. alliance and the change of the Korean Peninsula's geographical pattern from the composite perspective of the asymmetry between big and small countries. This study mainly follows the two logical lines: one is to comprehensively consider the "invariance" law of the alliance transformation by dialectically analyzing both the alliance's external environment and South Korea's internal affairs, and analyze the specific manifestation of the alliance's quantitative changes and the impact of the transformation direction on the future geopolitical map of the Korean Peninsula during the current Moon Jae-in period; the second is to estimate the gradual changes of the geopolitical mechanics in Korean Peninsula and Northeast Asia with the breakthrough of the DPRK's nuclear force and analyze China's future coping strategies. Overall, the effects brought by Donald John Trump to a certain extent dispersed the alliance based on traditional American values. Even in 2021, under the background of Biden's multilateral solid return, the ROK-US alliance returns to stabilize. It is a non-ignorable aspect that American hegemony will decline in the future, which is also the internal cause of the qualitative changes of the direction of the ROK-US alliance in post -Trump period and the safety structure in Northeast Asia.
\end{abstract}

Keywords: ROK-US Alliance, The Korean Peninsula, Geopolitics, Interactive Logic

\section{Research Background}

Based on the review of the mutual-regulated alliance between Donald John Trump and Moon Jae-in, the study inspects the contradiction between "American benefits first" by Trump and American global strategic alliance credibility. Therefore, we can further recognize the divergence between the alliance's commitment and the promised party, which exists in the Biden period. In the future, North Korea is constantly improving its nuclear deterrence capability against the United States. Once a nuclear war breaks out, there will be no absolute victory. Whether the United States is willing to be involved in a nuclear storm for its Northeast Asia allies, South Korea, remains considered. From this perspective, the United States' strategy toward South Korea in the future is still uncertain. From the perspective of the ROK, if the DPRK does not give up the "cliff" tactics of "nuclear weapons" in the future, the DPRK's nuclear issue will be automatically tied to the reunification of the South and North Korea, which will revive the alliance between the ROK and U.S anytime. During the Trump period, the relationship between South Korea and the United States appears to have a rift due to their policies toward the DPRK and the sharing defense expenses. However, it is undeniable that South Korea's current strategy toward the United States is specific. As early interviewed by Fox, Moon Jae-in affirmed that "the ROK-US alliance played an irreplaceable role in the Korean peninsula", "even if the ROK and the DPRK are unified, the ROK also needs U.S troops to stay" [8]. Because the sunk cost paid by the weak countries is far more than strong countries, the habitual dependence will also make South Korea unable to afford the heavy price after the breakdown of an alliance. It is unchangeable for South Korea to tie its security policy to its strong ally. This study will explore the alliance's process and development based on bilateral ROK's and US's strategic tracks and probes the ROK-US interaction laws based on the ROK 
decision-makers and then find outs how America's real power influences the ROK's policy design and how the ROK-US asymmetric interaction impacts on the regional structure changes in Northeast Asia. All above is the study's core and critical meaning.

The current domestic and foreign scholars have done several types of research on the transformation of the alliance. However, it is hard to accurately grasp the phased characteristics of the overall ROK-US alliance transformation and figure out why the alliance is vital at a particular time and alienated sometimes. There are four explanations relevant to alliance transformation.

Firstly, Michael Mandelbaum, a leading American scholar of international politics, argued that there was "Abandonment Fear" and "Entrapment Fear" between weak and strong countries in asymmetric alliances, which could cause a trust crisis mutually. Powerful countries fear being drawn into an unnecessary battlefield because of border conflicts with small countries and have "Entrapment" fear toward its allies' commitment. When an ally facing the third party's invasion, powerful countries will weigh the pros and cons under the temptation and then lose the small countries' trust for extending the protection. Then small countries fear being abandoned by dominant countries in alliance (For instance, based on American strategic contraction during the 1970s, Nixon's behavior of withdrawing troops from ROK had brought Park Chung Hee a strong sense of "Abandonment"; therefore, the divergence in asymmetric alliance began to happen).

Secondly, Glen H. Snyder, an American scholar in international relations theory and security studies, also believed that the reasons for the conflicts arising from alliances were from the different power statuses and the asymmetric degree of interdependence within allied countries [20]. When the equivalent exchange of independence for security is formed between the small countries and the big countries, the small countries' weak independence becomes the norm. However, when the big countries completely ignore the small countries' feelings and forcibly intervene in their policies, the small countries will also be dissatisfied. This is to say, immense power's coercive intervention in the small one within the same ally could trigger domestic resentments and weaken the overall unity.

Thirdly, Stephen Walt, the Harvard Kennedy Professor of International Relations, elaborated on the counterbalancing threat theory in his book "Origins of Alliances", arguing that the unity of alliances originates from "the third threat". Simultaneously, "the strength of common enemy consciousness" would indirectly influence the alliance structure's adjustment in the future. Under the anarchy of the international system, countries can only achieve their security through self-help. To form alliances with countries facing the same threat is a temporary means for countries to seek security through self-help. When external threats disappear or decrease, alliances' cohesion and effectiveness will also decrease, and the alliances will tend to disintegrate [15]. "Common security threat" is the preconditions of the alliance mechanism to survive. The previous American governments all have committed to seeking to defend the alliance's "target" - "new enemy", firmly against the opponents to reduce the allies' anxiety. When opponents feel threatened and surrounded, their hostile response stimulates allies to be closer together; when they conduct this, the counterparts become more fearful and hostile and the allies will rely more on their alliance, moving closer to the alliance [3]. According to this hypothesis, the Soviet Union served as the glue for the military alliance among the United States, Japan, and South Korea during the Cold War. North Korea's nuclear crisis in the post-Cold War period replaced the label of the former Soviet Union, in which the United States' alliance mechanism in Northeast Asia continues to be consolidated.

Fourthly, domestic scholar Zhou Jianren applied quantitative methods to recognize that small states' "self-help capability" was the key to the alliance's qualitative change, and then further proposed a causal logic mechanism from strategic disagreement, self-help capability to alliance disintegration [23]. He believes that the improvement of the weak countries' self-help ability in the alliance is the root of the disintegration of the alliance and the main factor to change the alliance structure. In this regard, South Korea's defense capability is the key to its independence-and eliminating the excessive dependence on the United States. The author thinks that the mainstream school studies the alliance transformation from a macro perspective of political power-while ignoring the contribution for alliance transformation from the microcosmic level of cognitive psychology research. Walter has a deep understanding of the cognitive root of alliance transition and thinks that the enemy's existence is the inevitability of alliance cooperation. However, he does not dig out the cause of the cognitive differences brought by "threats", precisely explaining the fundamental fuse of alliance transformation origin. Therefore, the author will highlight the importance of "man as the first image", the relevance between the toughness of the ROK parties' policies toward the DPRK and the changes of alliance's common enemies' effect. Along with the preferences of ROK's decision-makers, the ROK-US alliance's cooperation will also appear unstable, which indirectly influences the Korean peninsula's linkage mechanism.

\section{The Impact of ROK's Decision in Alliance Transformation on Korean Peninsula's Geopolitical Structure}

Alliance transformation is mainly divided into two types of changes, one is quantitative and the other is qualitative. Qualitative changes are three modes of change: "increase, decrease" or "self-dissolution" of the number of allied structures. So far, the transformation of the Korea-U.S. alliance has been limited to quantitative patterns in cooperation and has been influenced by different variables at different times. The closeness of the Cold War alliance 
between South Korea and the U.S. was mainly governed by the changing geostrategic value of the Korean peninsula, which in turn was coordinated with the expansion of U.S. global strategy. When the U.S. was in a period of strategic expansion, the strategic value of South Korea to the U.S. as a counterweight to its rivals increased, and vice versa. In the post-Cold War era, the ROK-US alliance was significantly influenced by South Korea's policy-making preferences, with the alliance strengthening and inter-Korea deteriorating when conservatives Lee Myung-Bak and Park Geun-Hye were in power, and the alliance weakening and inter-Korea making nice when progressives Kim Dae-Jung, Roh Moo-hyun and Moon Jae-in were in power. The current political spectrum in South Korea can be divided into the right-wing Conservative and the left-wing Progressive factions. The current opposition Liberal Korea Party belongs to the Conservative faction and is a pro-American mainstream with a strong policy towards the DPRK. In terms of security strategy, they generally rely on nuclear assets based on the Korea-U.S. alliance - and outward-looking strategy, i.e., "alliance dependence - security". The ruling United Democratic Party, on the other hand, belongs to the progressive camp and holds a soft policy toward the DPRK. It is typical of departing from the United States, whose national security policy tends to enhance South Korea's autonomous defense construction - an inward-looking strategy, i.e., "autonomous-self-help-security. As is mentioned above, the different factions of the rulers in South Korea have led them to adopt different policies toward the U.S. or achieve different levels of cooperation between the two Koreas [21]. Although there is no shortage of scholars who believe that North Korea and the U.S. are the key players in the Korean peninsula, South Korea has always been in a situation of "a small horse pulling a big cart" in dealing with relations between North Korea and the U.S. On this point, the author holds a different view, although South
Korea cannot directly exert influence on North Korea or the U.S., it can still act as an independent intervention variable to coordinate the ROK-US-DPRK interaction, which is subconsciously reshaping the Korean peninsula's geopolitical landscape. The preferences of South Korean policymakers will directly map out the way of inter-Korean relations, while the quality of inter-Korean relations will indirectly shift the modification of the ROK-U.S. alliance. Judging from the historical development in the past, South Korea is the only country that can push forward ROK-DPRK, the ROK-U.S, and the U.S- DPRK relations parallelly at the same time. To better understand the impact of South Korea's decision-making on the Peninsula region, it is necessary to study it in the logical framework of the U.S.-ROK-DPRK interaction to explore how the South Korean factions' decision preference builds the respective developing tendency of ROK-US alliance and ROK-DPRK relations during the Post-Cold War. The hypotheses are as follows:

Hypothesis 1: the ROK-US alliance weakens and inter-Korean relations slow down when South Korea's left-wing progressive forces are in power.

Hypothesis 2: the ROK-US alliance strengthens and inter-Korean relations deteriorate when South Korea's right-wing conservative forces are in power.

Hypothesis 3: As the elastic rope of the chain between the ROK and the US, when the ROK gets closer to the DPRK, the ROK will become estranged from the US. When the ROK gets estranged from the DPRK, the ROK will become closer to the US. The ROK can relieve the tension between the DPRK and the US to a certain extent.

To better compare the above hypotheses, the overall trend of the ROK-US alliance and the inter-Korean relations is summarized in Table 1 through the historical tracking method for reference.

Table 1. List of changes in US-ROK alliance and inter-Korean relations during the post-Cold War period

\begin{tabular}{lllll}
\hline Time (ROK) & The ROK President & $\begin{array}{l}\text { The U.S President } \\
\text { United States }\end{array}$ & The ROK Party & The ROK-U.S Alliance \\
\hline $1993-1998$. & Kim Young Sam & Bill Clinton & Right-wing & Strengthen \\
relations & Wearean Relation & Weaken \\
1998-2003. & Kim Dae-Jung & George W. bush & Left-wing & Weaken \\
$2003-2008$. & Roh Mu-Hyun & George W. bush & Left-Wing & Strengthen \\
$2008-2012$. & Lee Myung-bak & Barack Obama & Right-wing & Ameliorate \\
$2012-2016$. & Park Geun-Hye & Barack Obama & Right-wing & Deteriorate \\
Since 2016 & Moon Jae-in & Donald John Trump & Left-wing & Weaken \\
\hline
\end{tabular}

Note: Self-made by the author according to the course of history

South Korea's Alliance policy is an extension of partisan political struggle, which of its dispute mainly focus on the degree of softness and hardness of the policy toward North Korea and the strength of Korean-US. cooperation. and the combination of strength and weakness of the DPRK-Korean-US. is driven by the policy decisions of different South Korean leaders throughout the post-cold war. The divergence between the policies of the Liberty Korea Party (LKP) and the Common Democratic Party (CDP) towards North Korea is significant, with the former viewing North Korea as a "main enemy" and the latter viewing North
Korea as a "compatriot," which can be reflected in the revision and deletion of the definition of "North Korea" in successive ROK Defense Ministry white papers. which in turn has indirectly contributed to the changes in the bilateral alliance mechanism between the ROK and the US.

Through the observation, the interactive linkage in the triangle of US-DPRK-ROK could be concluded as below: when the left-wing faction such as Kim young Sam, Lee Myung-bak, Park Geun-Hye became the ruler, South Korea's diplomacy would be in the direction of "approaching the US and estranging the DPRK". They advocate to keep the 
existing framework of asymmetric alliance and reject any new revolution especially for withdrawal of the war operational command authority, so ROK's conservative governments are characterized by the national defense policy of "prominent alliance and weak autonomy". While if right-wing forces like Kim Dae-Jung, Roh Moo-hyun, Moon Jae-in become the presidents, the main direction of South Korea's diplomacy will be defined as "stabilizing the U.S and prioritizing the DPRK", which calling for modifying the unreasonable alliance structure, strengthening national defense forces, and supporting the early recovery of the operational command of the war. Therefore, ROK's progressive governments are featured by the national defense policy of "prominent autonomy, weakened alliance". According to the time axis, characteristics of different ROK-US alliance are as follows in the order: Kim Young Sam-Bill Clinton period in 1993-1998 (strengthened) ------Kim Dae-Jung-George W. Bush period in 1998-2002 (weakened)-------Roh Moo-hyun-George W. Bush period in 2002-2008 (weakened) ------Lee Myung-bak-Barack Obama period in 2008-2012 (strengthened)-------Park Geun-HyeBarack Obama period in 2012-2016 (strengthened) --------Moon Jae-in-Donald Trump period from 2017 - now (weakened). As seen above, the ROK-US alliance has fluctuated due to the different perceptions of the North Korean nuclear threat by different rulers in South Korea [21]. When progressive leaders like Kim Dae-Jung and Roh Moo-hyun pursued the "sunshine policy" towards DPRK, Inter-Korean relations began to ameliorate, for example, Roh Moo-Hyun's compassion on DPRK limited George W. Bush's pre-emptive to DPRK just as Moon Jae-in's PyeongChang Olympics shifted Donald Trump's direction from extreme pressure to engagement with North Korea. However, when Kim Young-sam, Lee Myung-bak, and Park Geun-Hye positioned North Korea as their adversaries, inter-Korean relations began to worsen. It will naturally drive the deterioration of U.S.-North Korea relations, while the traditional Korea-US alliance will grow closer as a result of frequent military cooperation against the north. What's more, it also intensifies great power geopolitical competition among the US, China, Russia, and sharpens regional security dilemma. Consequently, the governing philosophy of South Korea's policy-making elite controls the change in the direction of the transformation of the Korea-U.S. alliance in the post-Cold War era but also invisibly shapes the geopolitical structure of the Korean Peninsula, which shows that South Korea's cascading influence on Northeast Asian peripheral diplomacy cannot be underestimated. Also, under the political background of progressiveness and conservatives in South Korea, the changing characteristics of the triangular relations among DPRK-ROK, DPRK-US, and ROK-US are basically in accord with historical expectations which hypothesis 1, 2 can support simultaneously. Hypothesis 3 is extended based on Hypothesis 1 and Hypothesis 2. The strong effect of alliance with "common enemy" is correlated with alliance closeness, and the trend of relations between the DPRK-ROK and the ROK-US is inversely proportional. When the DPRK and the ROK get closer, the image of the common enemy between the ROK and the US weakens, followed by the weakening of the alliance cooperation. When the relationship between the DPRK and the ROK gets estranged, the image of the common enemy between the ROK and the US deepens, and the closeness of the alliance cooperation also strengthens. Therefore, Hypothesis 3 can be tested twice in the theoretical expectation of the alliance and the historical practice. As an intermediate variable, the political preference of South Korean leaders not only changes the inter-Korean relationship-but also promotes the change of the alliance between South Korea and the United States. In the meanwhile, South Korea's policy towards North Korea can also bind the United States to use force against North Korea, and subtly transform the degree of hostility between North Korea and the United States. Accordingly, the decision-making orientation of the South Korean leadership will simultaneously affect the dual trajectory of the transformation of the ROK-US alliance and the development of inter-Korean relations, this will influence the international climate of geopolitical changes on the peninsula.

\section{The Weakening of Alliance Transformation and the "Qualitative Change Prospect" of Northeast Asia}

According to the above historical expectations and assumptions, Moon Jae-in's Progressive party has placed the current alliance transformation in a weakened state. During this period, the weakened alliance mainly is as follows: 1 . there are strategic differences between South Korea's China-US balancing strategy and America's Indo-Pacific strategy to contain China. 2. there exists a contradiction between South Korea's struggle for its autonomy and America's dominance of the alliance. 3. there exists a paradox about legitimacy between South Korea's withdrawal of operational command and American military base in South Korea and American intervention on the Korean peninsula. 4. there exists the relevance between the increasing ROK-Japan conflicts and America's favor toward Japan. No matter whether the next elected decision-makers in South Korea repair the loose periodic changes of the existing alliance or not, in the short term, the alliance may show periodically bounce back strongly. But in the long term, it cannot affect the direct impact of the United States itself on the alliance. The gradual decline of the hegemony power of the United States has become the key internal cause of the collapse of the Northeast Asian Alliance, while the enhancement of the nuclear capability of the DPRK is the external cause of the release of the autonomy of South Korea and Japan. The interaction between the above two will weaken the overall cost of extended protection and regional control of the United States over South Korea and Japan. Therefore, no matter how much Biden returns to multilateralism after taking office, the range of return will still depend on the power roots behind 
the operation of U.S. military assets around the world. The declining hegemony of the United States is the premise of the qualitative change of the alliance, and this trend will deepen the suspicion of credibility between the Allies with the weakening of the leading country's own ability in the future. In the future, the strategic benefits of the United States and the choice of the security policy of South Korea will be a series of problems faced by the cooperation between South Korea and the United States. The reasons are as follows:

\subsection{The Risk Cost of the United States Goes up, and the Trust Crisis of the Alliance Deepens}

Credibility is a kind of soft cost of the alliance, which mainly refers to whether the alliance is so trusted by its members and rivals that allies will take practical and effective actions in a crisis or not [19]. United States' credibility towards Allies and adversaries has weakened in Trump's presidency. Allies' "abandonment" and "entrapment" have increased, and it has become more difficult to continue to promote lasting agreements with adversaries [11]. The alliance based on America's traditional values has also fallen into a tool alliance under the naked pursuit of profits by capital. How Biden adjusts the relationship in the future may improve the relationship between South Korea and the United States to a certain extent, but it cannot affect the uncertainty of the game prospect between North Korea and the United States. The opportunity cost of the United States under multiple strategic choices increases. On November 29, 2017, the successful launch of the Hwasong-15 intercontinental missile by the DPRK marked the completion of the whole process from quantitative to qualitative change of the DPRK's nuclear capability, extending its coverage from the original edge of Alaska and Guam to the whole territory of the United States.

In the future, the United States will reevaluate its nuclear deterrent against the DPRK and the dynamics on the Korean Peninsula will also shift. South Korea will face a new and intractable problem, which is the "Mainland First" principle of the United States may lead to the trust crisis in the alliance with South Korea. As U.S. Secretary of State, Mike Pompeo said in an interview with Fox News on January 11, 2019, "there are a lot of ideas that we're discussing how to continue to reduce the threat to Americans. The final objective is the safety of American citizens. What's more, about the opinions that the DPRK launched many test firings of rockets before the 2019 ROK-US joint military exercise" [7]. On August 9, 2019, Trump also said that these missiles were short-range missiles and reiterated that the DPRK had not broken its commitment to suspend nuclear tests [10]. This reflects Trump's temporary shift from "extreme pressure" to "strategic tolerance". On the one hand, the US is trying to maintain the tacit agreement reached between the US and the DPRK to "exchange the suspension of joint military exercises for nuclear freeze". Trump, on the other hand, has imitatively downplayed his Allies' security concerns as he weighs the stakes of the threat. It can be seen what Trump cared most at that time was to prevent the DPRK from further acquiring intercontinental long-range missiles (ICBM) capable of striking the US mainland, rather than medium and short-range missiles that could provide realistic deterrence to South Korea and Japan. There are a few aspects to consider about Biden's future strategic shift. First, would the United States have the resolve to engage in a nuclear confrontation with North Korea to ensure the security of its Allies if either DPRK-ROK or DPRK-Japan relations were in conflict and chaos? Second, how does Biden balance the primacy of U.S. interests with a recommitment to South Korea's security? Third, will the US make defection more likely because the US has paid less and less for its allies? Only when the above questions are definitively answered can we find out the causes and solutions of the current new dilemma between the US and the ROK.

So we need to start with why South Korea and the United States are in dispute about the means to resolve the nuclear crisis As is known to all, the United States usually adopts tough pressure and intimidation on the DPRK and is not very sensitive to the perception of whether there is conflict on the peninsula, while the ROK advocates peaceful negotiation and dialogue to resolve the crisis, and remains highly alert to the war. The nature of the international system defines the space for strategic choice for small countries, while the comprehensive strength and geographical position define the means and methods of strategic choices for small countries [18]. Once situations get out of hand, Seoul, just 40 kilometers from the 38th parallel, will be Pyongyang's main target of attack at close range. Washington with a distant advantage across the Pacific Ocean, on the other hand, is the only country that can pull rapidly out from Asia, which Moon Jae-in understands well under his policy of peace on the peninsula. Since conflicts have a more serious impact on small countries, the avoidance and control of conflicts are important in their security [18]. Secondly, John J. Mearsheimer also made a related argument in "The Tragedy of Great Power Politics": "Geography is an important factor in the abdication of responsibility", which in turn affects the probability of defection [5]. According to the analysis of the distance between the Six-Party Talks' members and the DPRK, the magnitude of the abdication of responsibility is as follows: The United States $>$ Japan $>$ Russia $>$ China $>$ South Korea. The greater a country's dependence on an alliance, the stronger commitment to the alliance is, and the higher the risk of being involved is [3]. If the situation on the Korean Peninsula is out of control, the non-regional power (the United States), out of fear of "nuclear involvement", does not rule out the possibility of reducing its commitment to early withdrawal of troops or betraying the alliance by sacrificing part of its troops in South Korea. Dong-Hun Shin, a South Korean scholar, also said the United States cannot easily decide to take military measures against North Korea because the US believes North Korea has a nuclear capability that can attack the U.S. mainland. In the United States, which puts its interests first, there are many views in South Korea about whether the US makes a firm decision to send troops to the South when a North Korean nuclear missile could fall on the U.S. mainland, causing hundreds of millions of casualties [14]. Facts have also proved that the United States has 
always been the provider of aid, while South Korea is only the recipient of aid. This unilateral relationship is also reflected in the relative influence of its Allies. The United States often makes major policy decisions unilaterally, which will cause serious consequences to South Korea, and exerts considerable influence on South Korea's internal and diplomatic affairs [4]. There is a serious information asymmetry between South Korea and the United States in terms of strategy, and South Korea is always in a kind of hindsight to the strategic adjustment of the United States. Therefore, the future alliance between South Korea and the United States will also face new challenges from the uncertain strategy of the United States under the nuclear status of the DPRK. This is also the potential reason for South Korea to acquire nuclear weapons independently, and the nuclear dominoes in Northeast Asia are also the "Waterloo" that eventually disintegrates the American alliance mechanism.

\subsection{The Cognition of the Main Enemy Is Different, and the Benefits of the Alliance Continue to Weaken}

During the Moon Jae-in period, the alliance between South Korea and the United States was basically in a state of "disagreement on North Korea policies and weakened alliance benefits". In an asymmetric alliance, the weakening of the alliance consists of one variable and two conditions. First, one variable is whether there are fundamental strategic differences between member states on how to deal with the main enemy against whom the alliance is targeting [22]. This reflects the differences between the ROK and the US in their "policy towards the DPRK" and the "path to denuclearization". From the "complete, verifiable and irreversible" denuclearization insisted on by Pompeo during his visit to the DPRK, namely (CVID) denuclearization model, the improvement of US-DPRK relations is directly linked to the denuclearization process. Unlike the one-time denuclearization roadmap, Moon is more in favor of "phased denuclearization" and is in line with China and Russia's insistence on unconditional dialogue with the DPRK and partial lifting of sanctions. Besides, the two conditions mainly refer to the enhancement of the self-help ability of the weak Allies and the disappearance of the common threat.

First, we need to talk about the capacity of small countries to help themselves. When a small country can resist foreign invasion with its strength and has a strong "self-help" ability, its dependence on the big country will be reduced. When strategic differences occur between the two countries, the tolerance of the small country to the big country will also be reduced, and the alliance between the two countries will have the risk of breakdown. On the contrary, when a small country has poor self-help ability and survives with other helps under the extended protection of the big country, its dependence on the big country will increase. Even if the strategic differences between the two countries are serious, the small country will choose to sacrifice itself to satisfy the big country and surrender part of its sovereignty to ensure its survival. In this case, the alliance is still unbreakable. Therefore, the capability of weak countries to help themselves is the key to the weakening or disintegration of the alliance. In the process of getting rid of or reducing its dependence on the United States, South Korea's self-help ability was first reflected in the transfer of wartime operational command (OPCON). Roh Moo-hyun agreed to take back wartime operational command in 2012 at the South Korea-United States summit in September 2006, but this was postponed by both Lee Myung-bak and Park Geun-Hye governments. If the wartime operational command transfer is achieved as soon as possible, it will bring structural changes to the combat system of the South Korea-U.S. joint forces and the Japanese support system for the U.S. forces stationed in South Korea, which will encourage independent military operations of the South Korean military [12]. The current commander of the ROK-US joint military is headed by the U.S. while the deputy commander is South Korean. In that case, the U.S. commander would take command of the South Korean forces when the full-scale war breaks out. If OPCON was taken over to South Korea, the commander of the ROK-US joint military would be a South Korean four-star general who would take control of American forces. After the return of the wartime operational command, South Korea will regain military sovereignty, and greatly improve the self-help ability. If the next South Korea's President is the Progressive Party, the ROK-US alliance structure will weaken [1].

Second, the strength of the common threat signal is also an important variable affecting the alliance. Since the value of alliance, cooperation derives from common threats, when the threat signal is strong, the benefits of the alliance increase, and the cost of maintaining the alliance reduces. Then the alliance relationship becomes close, and both sides have a strong willingness to invest in the alliance. When the common threat signal is weak, the benefit of alliance cooperation decreases, the cost of its maintenance increases. Then the alliance relationship is slack, and the willingness of both parties to invest in the alliance decreases. After the reciprocal improvement of relations between the DPRK-ROK and the ROK-US in 2018, the common threat (the DPRK nuclear issue) has become less prominent, and the benefits of joint defense between the ROK and the US have also declined significantly. On the one hand, the United States is shifting the strategic burden of its Allies, greatly reducing the cost of keeping its allies and increasing the probability of betrayal. On $25^{\text {th }}$ August, in the G7 Summit and Abe Summit about the end of the ROK-US autumn military drill, Donald John Trump said "As much as I would like to advise all the staff around me not to do this [war games], I let them do what they want. I don't want to interfere. If you want to do it, you can do it. you think it is necessary, but I think it is a complete waste of money, etc." [16]. On the other hand, to maintain ROK-DPRK relationship fellow in the good development, South Korea is more reluctant to invest too much to irritate North Korea, that's why ROK-US joint military exercises are reduced and South Korea's dependence on the United States is lessened. According to the previous data of South Korea's National Defense White Paper, the annual frequency of Moon's joint military exercises with the United States plummeted from 102 in 2017 to 77 in 2018, a year-on-year drop of nearly 25 percent, with the most significant 
change in the number of joint exercises. It can be shown that the strength of common enemy consciousness and alliance structure closely interact with each other.

Above all, the security benefits brought by the Alliance are proportionate to the degree of threats. The greater threat is, the more benefits the alliance has. However, the security benefits are inversely proportionate to allies' self-help ability. The stronger self-help is, the greater the ability of their security is, and the less reliance on Allies is, and the smaller the alliance's value to allies is [22]. In the future, South Korea will not be able to get rid of the alliance constraints from the United States until it has adequate defense capability to cope with the expanding nuclear force of North Korea. Therefore, South Korea's policy towards the United States will remain stable. In the future, with the huge time cost of the DPRK-US negotiations, the failure of the engagement strategy will make both sides in a state of loss. The DPRK and the US could return to the original "crisis-conflict" spiral mode or for the DPRK to break through the critical value (the 7th nuclear test). In the tense atmosphere on the Korean Peninsula, the conservative party in South Korea will tend to return. It is still unknown that how long Moon Jae-in's peace policy on the Korean Peninsula can be maintained, which will depend on the degree of tension between the US and the DPRK. In contrast, the strategic flexibility of the United States is very high. With the gradual strengthening of the anti-deterrence effect of the DPRK against the United States, when the alliance benefits reduce to the critical point of qualitative change, the cost of the United States' commitment breach will reduce simultaneously. During repeated haggling between the ROK and the US, the difference in quantity between the payoffs will be an important determinant of cooperation [6]. In the future, when Biden in office, we can't rule out that alliance will be bounced to the phased reinforcement. But during the Post Covid-19 era, if the American power declines, the only choice is to reduce the alliance investment and abdicate the international responsibilities. The strategic contraction will subsequently lead to a ratio imbalance of alliance benefits. Therefore, the interaction failure will hinder the cooperation. As a result, the alliance will not rule out the possibility of strengthening the quantitative change in a phased reinforcement till the possibility of long-term qualitative change. The speed of the United States' power recession will be an uncertain factor. Therefore, the path to solving the asymmetric alliance between the ROK and the US in the future is for the weak countries to increase their autonomy by pursuing multiple security strategies including bilateral alliance and cooperative security. Therefore, it will become very urgent to promote the construction of multilateral military control mechanism in Northeast Asia to suspend the arms spiral of the three countries [9]. On the one hand, it can create more space for South Korea to extend its survival and reduce its dependence on the asymmetric alliance between South Korea and the United States. On the other hand, it will place North Korea in a multilateral security framework composed of China and Russia to restrain the escalation of the North Korean nuclear crisis and weaken the pressure of South Korea on the nuclear offensive against North Korea. The multilateral security path can not only stabilize the minimum deterrence between the DPRK and the US but also dilute the impact caused by the strengthening of the alliance between the ROK and the US on the geopolitical tension in Northeast Asia.

Table 2. List of influencing factors of the ROK-US alliance.

\begin{tabular}{|c|c|c|c|c|c|c|c|}
\hline \multicolumn{4}{|c|}{$\begin{array}{l}\text { The Inherent Relevance between the Take-over of OPCON and the } \\
\text { ROK-US Alliance }\end{array}$} & \multicolumn{4}{|c|}{$\begin{array}{l}\text { Intrinsic correlation between Inter-Korean Relations and the Alliance } \\
\text { between the DPRK-ROK and the ROK-US }\end{array}$} \\
\hline Independence & Alliance & $\begin{array}{l}\text { Strategic } \\
\text { Differences }\end{array}$ & $\begin{array}{l}\text { Alliances } \\
\text { Breakdown }\end{array}$ & $\begin{array}{l}\text { Common } \\
\text { Threat }\end{array}$ & $\begin{array}{l}\text { Alliance } \\
\text { Benefits }\end{array}$ & $\begin{array}{l}\text { Cost of } \\
\text { Alliance }\end{array}$ & alliance \\
\hline Self-help & Low & Low & High & No & Small & High & Relaxed \\
\hline Others-help & High & High & Low & Yes & Big & Low & Close \\
\hline
\end{tabular}

Note: The author made the table according to Zhou Jianren's book Heading for Breakdown -- The Mystery of Weak Countries Withdrawal from the Alliance

\section{Conclusion}

Through the combination of historical reflection and current events, this paper systematically interprets the subtle linkage mechanism on the Korean Peninsula between the ROK-US alliance and the DPRK-ROK relation. Utilizing visual dislocation between the ROK and the US, we explore the different value orientations of alliance towards strong or weak countries. During the transformation of ROK-US relations, the South Korean policies towards the US remain a state of quantitative change. While the American policies towards South Korea remain a state of quick qualitative change e.g. for Park Chung Hee, it was a surprise to retreat the troops. As long as the ROK satisfies one of the two conditions (reunification has not been realized or its national defense has not been fully independent), no matter how the alliance is transformed in the future, the ROK does not have the strength and capital to withdraw automatically from the alliance in the short term. Since the goal of small countries' security policy is not to change the international system dominated by big powers or to have the ability to change the status quo, but to maintain the status quo, their ultimate criterion is survival rather than victory [17]. Therefore, the initiative and regulatory power of the break-up of the ROK-US alliance will still be in the hands of the US and will become a bargaining chip for the US to seek benefits from the ROK and pressure on the ROK.

The different transformation directions of the ROK-US alliance will shape the different geographical and spatial trends of the peninsula. As a close neighbor of the ROK, the Korean Peninsula is of great geostrategic value to China. As a staunch defender of peace on the Peninsula, China should pay attention to the following aspects:

First, if China continues to act as a mediator on the Korean Peninsula and maximizes support for inter-Korean reconciliation and cooperation, South Korea will be less 
dependent on the United States. If the relations between the DPRK and the ROK improve, there will be differences between the ROK and the US on how to deal with the main enemy of the alliance, which will increase the cost of maintaining the alliance between the ROK and the US. All these will form resistance to the consolidation of the American alliance system in the Asia-Pacific region, to ensure the strategic survival space of China [22].

Second, the dispute between Korea and Japan is a manifestation of the travails of geopolitical transformation. Owing to the history and trade problems between South Korea and Japan, bilateral relations fell to rock bottom since the establishment of diplomatic ties in 1965. Faced with the pressure from North Korea and South Korea, to avoid being in diplomatic isolation, Japan actively improves the relationship with China, which can objectively promote the reconstruction of the geopolitical landscape in Northeast Asia to some extends. Therefore, China should actively participate in shaping the new international relations in Northeast Asia to some extends.

Third, we need to reshape and upgrade the China-DPRK friendship. An independent North Korea with self-defense capability not only serves as an important geostrategic buffer zone but also the close relations with North Korea will help enhance China's right of speech in the Korean peninsula's affairs. China should also help the DPRK to get rid of sanctions and isolation in an appropriate way, so that North Korea can gradually integrate into the region and the international community, which will be more favorable to China geo-strategically.

Fourth, it is necessary to moderately support South Korea. In the tug of war between South Korea, the United States, and Japan, China should prevent South Korea from sacrificing its independence to completely join the US-Japan ocean camp to contain China because of South Korea's overwhelming pressure. China should assess the situation and provide timely and appropriate help to South Korea during its difficult period. Appropriate intervention by China can prevent the formation of the military alliance system among the United States, Japan, and South Korea, which is a symbol of the Cold War.

Fifth, the Asia-Pacific alliance mechanism of the United States still plays an important role in maintaining the global nuclear non-proliferation treaty, which is also an effective safety valve to restrain the independent development of nuclear weapons by South Korea and Japan for a long time. In East Asia, nuclear weapons are put on ice in South Korea, Taiwan, and Japan capable of producing nuclear weapons, but not yet on a large scale [13]. British scholar Barry Buzan thinks that there are three nuclear thresholds in Asian countries or regions (Japan, South Korea, and China Taiwan). They are implementing the invisible deterrent strategy, that is, if their regional environment militarily becomes more threatening, or the promise of the United States' support loses credibility, they three can quickly become a nuclear weapon country or region [2]. There is no doubt that the disintegration of the Asia-Pacific alliance system of the
United States will lead to the escalation of conflicts among small countries in Northeast Asia and the increase of nuclear proliferation risk.

As for the above, Northeast Asia needs to establish a new arms control mechanism or multilateral security organization to solve these contradictions, which is an unavoidable strategic issue for China, South Korea, and Northeast Asian countries.

\section{References}

[1] After the Transfer of Wartime Operational Command, the ROK Senior General Will Be the Joint Commander of the ROK and the US. (2019). South Korean Central Daily Chinese Website:

https.//chinese.joins.com/gb/article.aspx?art_id=190123\&cate gory $=002002$ [2020-08-11].

[2] Barry Buzan, Ole Waver. Pan Zhongqi, Sun Xia, Hu Yong, Zheng Li Translated. (2010). Regions and Powers: The Structure of International Security, p. 91.

[3] Glenn H. Snyder. (1984) The Security Dilemma in Alliance Politics. World Politics, Vol. 36, No. 4, pp. 467-477.

[4] Han Sungjoo. (1980) South Korea and the United States. The Alliance Survives. Asian Survey, Vol. 20, No. 11, p. 1077.

[5] John J. Mearsheimer. Wang Yigui, Tang Xiaosong Translated (2014). The Tragedy of Great Power Politics. Shanghai Century Publishing House, pp. 301-302.

[6] Kenneth A. Oye. Tian Ye Translated (2010). Cooperation Under Anarchy. Shanghai Century Publishing House, pp. $5-11$.

[7] Li Dunqiu. (2013) The Second Meeting of Kim and Trump: the Main Reason and Solution. China Youth Daily, Version 4.

[8] Moon Jae-in: After reunification, the US Troops also need to stay. (2018) $\quad$ Foreign http://news.sina.com.cn/w/2018-09-26/doc-ifxeuwwr8280290. shtml.

[9] Min Hyoung Park. (2011). A Comparative Security System in Northeast Asia-the ROK Strategic Choices, The Journal of East Asian Affairs, Vol. 25, No. 1, pp. 87-88.

[10] Mr. Trump Said He Received a Three-page Handwritten Letter from Mr. Kim. (2019) Ecns.cn: http.//finance.chinanews.com/gj/2019/08-10/8922504.shtml.

[11] Matteo Dian. (2018) Trump's Mixed Signals toward North Korea and US-led Alliances in East Asia. The International Spectator, Vol. 58, No4, p. 2.

[12] Nam Kwang Kyu. (2019) The Moon Jae-in Administration's North Korea Policy and Korea-US Relations. Asian Education and Development Studies, Vol. 8, No. 1, p. 62.

[13] Paul Rogers, Xiao Huanrong Translated. (2004). Global Security in the Twenty-first Century: Losing Control. Xinhua Press, p. 93.

[14] Shin Dong-Hun. (2018). North Korea's Nuclear Strategy Looked at through Nuclear Resys, Korean Military History Journal, Vol. 74, No. 1, pp. 145-163. 
[15] Stephen M. Walt, Zhou Piqi translated (2007). The Origin of Alliance: Peking University Press, pp. 2-183.

[16] Trump: Kim Jong-un Was Not Happy about the Military Exercises, Which I Also Thought a Waste of Money. (2019). South Korean Central Daily Chinese Website: https.//chinese.joins.com/gb/article.aspx?art_id=192199\&cate gory $=002002$ [2020-07-22].

[17] Wei Min. (2014). Small State and International Relations. Peking University Press, p. 279.

[18] Wei Min. (2016). Small State and International Security. Peking University Press, pp. 59-78.

[19] Zhang Jingquan, Liu Lili. (2016). Cost and Dilemma: A New Exploration of Alliance Theory. Northeast Asia Forum, No. 2, p. 14.
[20] Zhang Xuekun, Ou Xuanxi. (2018) Involvement Risk and Avoidance in Alliance Politic. International Forum, No. 1, p. 56.

[21] Zhao Weining, Yang Luhui. (2014). Analysis of the Influence of Domestic Politics in South Korea on the alliance between South Korea and the United States. Socialism Studies, No. 4, pp. 151-152.

[22] Zhou Jianren. (2018). Heading for Breakdown -- The Mystery of Weak Countries Withdrawal from the Alliance. Social Sciences Academic Press, pp. 51-222.

[23] Zhou Jianren. (2013). Strategic Divergence, Self-help Capability and Alliance Disintegration. World Economics and Politics, No. 1, p. 67. 